\title{
RESEARCH PAPER \\ Spatial patterns over a 24-year period show an increase in native vegetation cover and decreased fragmentation in Andean temperate landscapes, Chile
}

\section{Robert Petitpas $^{1,2}$, José Tomás Ibarra ${ }^{1,2,3}$, Marcelo Miranda ${ }^{4,5}$, and Cristián Bonacic $^{1,2}$}

${ }^{1}$ Pontificia Universidad Católica de Chile, Facultad de Agronomía e Ingeniería Forestal, Departmentamento de Ecosistemas y Medio Ambiente, Laboratorio de Vida Silvestre Fauna Australis. Vicuña Mackenna 4860, Santiago, Chile.

${ }^{2}$ Pontificia Universidad Católica de Chile, Facultad de Ciencias Sociales, Departamento de Antropología,

Centro de Estudios Interculturales e Indígenas (CIIR). Vicuña Mackenna 4860, Santiago, Chile.

${ }^{3}$ Pontificia Universidad Católica de Chile, Campus Villarrica, Centro de Desarrollo Local (CEDEL). Bernardo O'Higgins 501, Villarrica, Chile.

${ }^{4}$ Pontificia Universidad Católica de Chile, Facultad de Agronomía e Ingeniería Forestal, Departamento de Ecosistemas y Medio Ambiente. Vicuña Mackenna 4860, Santiago, Chile.

${ }^{5}$ Centro de Ecología Aplicada y Sustentabilidad (CAPES). Av. Libertador Bernardo O’Higgins 340, Santiago, Chile.

\begin{abstract}
R. Petitpas, J.T. Ibarra, M. Miranda, and C. Bonacic. 2016. Spatial patterns in a 24year period show a case of increase forest cover and decrease fragmentation in Andean temperate landscapes, Chile. Cien. Inv. Agr. 43(3):384-395. Changes in landscape pattern were studied in a temperate landscape of the La Araucanía Region, Chile. Using aerial photographs from 1983 and 2007, we created land use/land cover maps. We then quantified the changes in composition and configuration by using landscape metrics and an adjacency matrix. By 2007, the dominant land cover had changed from agriculture to native vegetation. Residential areas showed the largest relative increase (670\%) and had significant adjacency with native vegetation. The native vegetation increased by 375 ha, but the number of patches decreased by $45 \%$ and the mean patch area increased by $124 \%$, which indicated that fragmentation decreased. The growth of tourism and the preference for "natural" spaces by new residents are suggested as the main drivers of this native vegetation recovery. Understanding the process of forest recovery may be helpful for reversing the general trend of forest loss in temperate forests of South America. This research is a first approach in exploring specific cases of native vegetation recovery and decreases in fragmentation in this Global Biodiversity Hotspot.
\end{abstract}

Key words: Fragmentation, landscape change, native vegetation recovery, temperate forest.

\section{Introduction}

The landscape, as a study unit, is suitable for understanding the effects of human activity on ag-

Received December 16, 2015. Accepted October 14, 2016. Corresponding author: rcpetitp@uc.cl ricultural and forested ecosystems because society perceives and interacts with the environment on a landscape scale (Moore-Coyle and Scott, 2005). Landscape planning approaches usually involve areas that are sufficiently large for the conservation of biodiversity and ecosystem functions (Newton et al., 2009). Several ecological processes 
are affected by changes in landscape structure (Newton et al., 2009), including dispersion, the reproduction and survival of animals (Parody et al., 2001), biogeochemical and hydrological cycles (Hunsaker and Hughes, 2002), seed dispersion and soil protection (Newton et al., 2009).

The Valdivian Temperate Rainforest of southern South America is considered a Global Biodiversity Hotspot for conservation (Lara et al., 2012). Although some forest remnants remain undisturbed, most stands have been replaced or are threatened by anthropogenic activities (Lara et al., 2012; Altamirano and Lara, 2010). In Chile, most landscape change studies have reported the fragmentation and loss of native temperate forest and an increase in exotic tree plantations (Echeverría et al., 2006, 2012; Altamirano and Lara, 2010; Carmona and Nahuelhual, 2012, Miranda et al., 2015). Although cases of native vegetation recovery have been reported for Mediterranean areas of central Chile (Hernández et al., 2015, 2016), there have been few empirical studies on cases of native vegetation recovery in temperate landscapes (Díaz et al., 2011; Echeverría et al., 2012; Zamorano-Elgueta et al., 2015).

According to the land use and vegetation cadastre of the Chilean Forestry Service (CONAF), between 1993 and 2007 native forest decreased in 39,827 hectares of the La Araucanía Region of south-central Chile (CONAF, 2009). By 2007, the remaining land covered by native forest represented $29.5 \%$ (937,312 ha) of the region. In addition, the cadastre reported an increase of 220,854 ha (representing $18.0 \%$ of the total area) for exotic tree plantations and an increase of 2,287 ha (representing $0.4 \%$ of the total area) for urban and industrial land use. Agriculture showed the highest decrease in the area, decreasing in 116,829 ha, during the same time period (this land use represents $24.5 \%$ of the total area). Within the La Araucanía Region, Pucón County maintains an important cover of native forest, which is considered essential for wildlife conservation (Ibarra et al., 2012; Gálvez et al., 2013; Ibarra and Martin, 2015). In contrast, this county has the highest annual population growth rate in the district (INE, 2008), and during the summer, the number of tourists can double or even triple the resident population (Municipalidad de Pucón, 2007). In this context, the area is suitable for studying the dynamics between society and nature at the landscape scale.

The aim of this study was to measure and analyze the changes in spatial patterns, between 1983 and 2007, in a landscape where the economic activities and social interactions with the environment are changing. In particular, we analyzed the changes in landscape composition and spatial configuration, paying special attention to changes in native vegetation cover. Moreover, the implications of these findings for conservation and the possible drivers of landscape change are discussed. We used landscape ecology as a methodological framework to study the changes in spatial patterns. Specifically, we used landscape metrics to assess the landscape structure (Li et al., 2005) because these metrics allow the spatial patterns across temporal scales to be quantified (Pauchard et al., 2006).

\section{Materials and methods}

\section{Study area}

The study area $(4,001 \mathrm{ha})$ was located in a premountainous valley $\left(39^{\circ} 17^{\prime} \mathrm{S}-71^{\circ} 48^{\prime} \mathrm{W}\right)$ in Pucón, La Araucanía Region, Chile (Figure 1). Human settlements, agriculture and exotic tree plantations are located in the bottoms of valleys, and old-growth native forests are situated in both public and private protected areas above 700 masl (Ibarra et al., 2012). An important cover of secondary native forest can be found in the lowlands, dominated by Lophozonia obliqua. The main agricultural activities include cattle and sheep rearing in artificial pastures, and there is a relatively small surface covered by exotic tree plantations (Pseudotsuga menziesii, Pinus radiata and Eucalyptus globulus). San Pedro 
Village, with a population of 187 (Municipalidad de Pucón, 2007), is located within the study area. Additionally, two rivers and a highway pass by the study area.

\section{Land use/land cover classification}

Land use/land cover maps for two different years (1983 and 2007) were made from digital aerial photos (Figure 2). Both photos where obtained from the Photogrammetric Service of the Chilean Air Force (SAF). The photo from 1983 $(1: 30,000)$ was georeferenced and rectified with OrthoEngine (PCI Geomatics), using a pixel size of $1.2 \mathrm{~m}$. The photo from 2007 was georeferenced and rectified at scale of 1:40,000 with the same pixel size. The landscape features were classified into one of seven land use/land cover classes by using a visual photo-interpretation technique that utilizes texture, grain and color to interpret patterns, which resulted in two maps in vector format that were then rasterized. A minimum map unit of 0.05 ha was used. Quantitative clas- sification assessment was not necessary because every patch was classified manually from the high-resolution photographs, which allowed the visual identification of landscape elements. Visual identification is frequently used to validate data in computer-based methods, but in our case, the entire area was visually classified due the extent of the study site. The accuracy of the land use/land cover classes was assessed by ground validation.

The land use/land cover classes identified were as follows: 1) Native vegetation: mainly secondary forest dominated by Lophozonia obliqua and Nothofagus dombeyi and old-growth forest dominated by Laureliopsis philippiana and Saxegothaea conspicua. Some patches of shrubland were also identified. 2) Agriculture: agricultural lands, mostly artificial grassland for livestock and, to a lesser extent, crops. 3) Exotic tree plantation: mono-specific tree plantations of exotic species, mainly Pseudotsuga menziesii, Pinus radiata and Eucalyptus globulus. 4) Mixed forest: mixed forest patches of native and exotic species. 5) Settlement: permanent and secondary residences and some

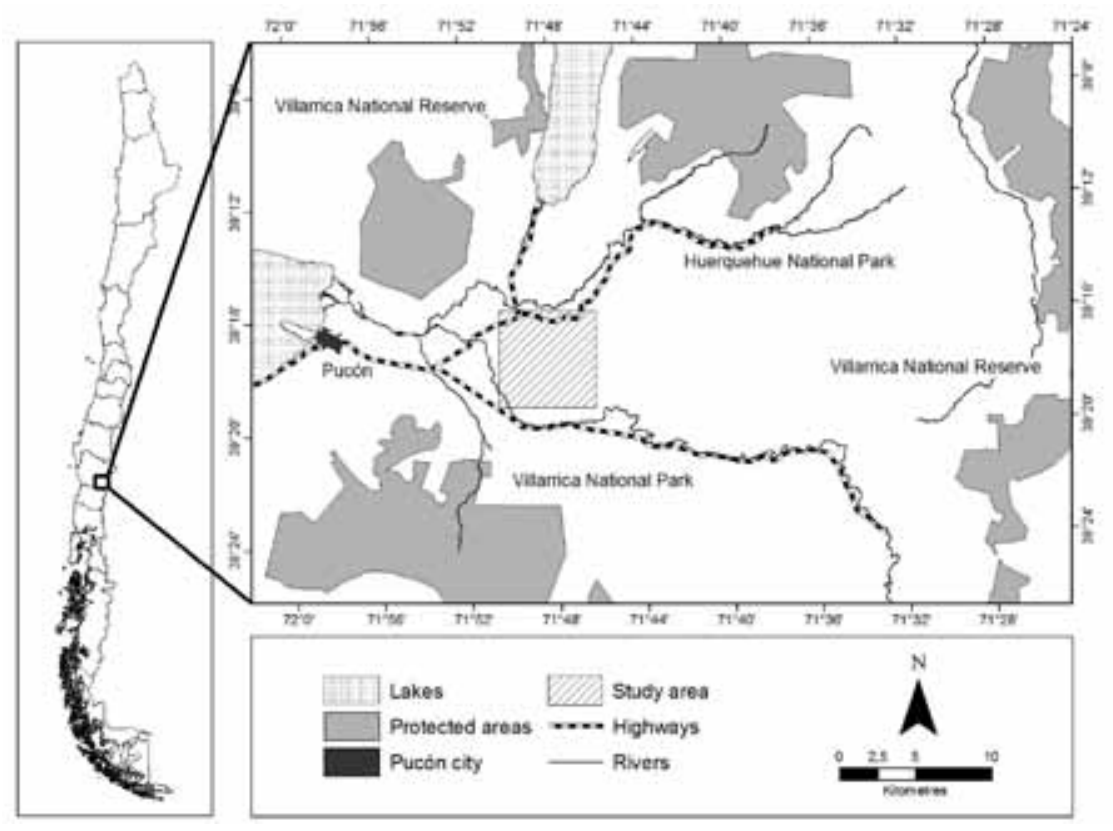

Figure 1. Study area and the specific location of the case study in temperate forests of the La Araucanía Region, south-central Chile (left). 
commercial buildings. 6) River: main permanent rivers (this class includes only what is visible on the aerial photograph). Riparian areas that were not visible from above due to vegetation cover were included in the respective vegetation class. 7) Highway: main land transport routes (as in the river class, the portions that were not visible from above were not included).

Landscape- and class-level metrics and an adjacency matrix were calculated using Fragstats 3.3 (McGarigal et al., 2002). Metrics were selected according to their suitability for the study, and redundant metrics were discarded (Li et al., 2005). Changes in landscape composition were evaluated by the area and percentage of landscape occupied by each class. The diversity index, evenness index and largest patch index were calculated for each year as well. These metrics quantify the diversity of land use/land cover classes and the evenness in the spatial distribution of landscape areas between the classes (McGarigal et al., 2002). Metrics were also used at a class level to measure changes in the native vegetation structure such as fragmentation, isolation and connectivity (Pauchard et al., 2006). For a detailed description of the metrics, see McGarigal et al. (2002). The adjacency matrix was used to explore the vicinity relations among classes. This matrix was built by counting the pixels of one class that were adjacent to the pixels of another class. The diagonal of the matrix represents the number of pixels adjacent to pixels of the same class; these values were discarded because they represented more than $96 \%$ of the adjacency for each class. This occurred due to the small pixel size in relation to the size of patches. Finally, the values were transformed into percentages of total neighboring pixels for each class.

\section{Results}

\section{Landscape composition}

For both 1983 and 2007, the dominant classes in the landscape were agriculture and native vegetation.
In $1983,54.70 \%$ of the landscape was covered by agriculture and $40.43 \%$ by native vegetation. By 2007 , native vegetation became the dominant class, covering $49.78 \%$ of the landscape, and agriculture decreased to $38.55 \%$. The coverages of settlement and exotic tree plantation also increased from 1983 to 2007 (Figure 3). Mixed forest appeared as a new class of land cover during the study period and represented $1.10 \%$ (44.09 ha) of the landscape by 2007 . The largest decrease in area was observed for the agriculture class, decreasing from 2,189.10 ha in 1983 to $1,542.50$ ha in 2007. River and highway classes did not change in area; however, some of their sections were no longer visible by 2007 because of the increase in vegetation cover. The settlement class showed the greatest change, increasing by $670.26 \%$ from 26.39 to 203.25 ha, which represented $0.66 \%$ (1983) and $5.08 \%$ (2007) of the study area.

The Simpson diversity index (SIDI) and Simpson evenness index (SIEI) (both range from 0 to 1) increased from 0.54 to 0.60 and from 0.63 to 0.68 , respectively, from 1983 to 2007 . These indices showed little variation in this period because in 2007, the landscape was still dominated by only two land use/land cover classes. The Largest patch index (LPI) changed from 42.17 to 38.80 ha, which also indicated a more even distribution of classes in the landscape.

\section{Adjacency matrix}

The adjacency matrix shows the percentage of edge shared by the different classes (Table 1). In 1983, native vegetation was mainly adjacent to agriculture ( $98.18 \%$ of its edges), but in 2007 , the adjacency percentages with other classes increased, especially with settlement (from 0.28 to $12.64 \%$ ). Agriculture decreased its adjacency with native vegetation and increased its adjacency with exotic tree plantation. In contrast, exotic tree plantation did not show any major changes. The new class, mixed forest, mostly appeared adjacent to agriculture $(79.77 \%)$ and, 


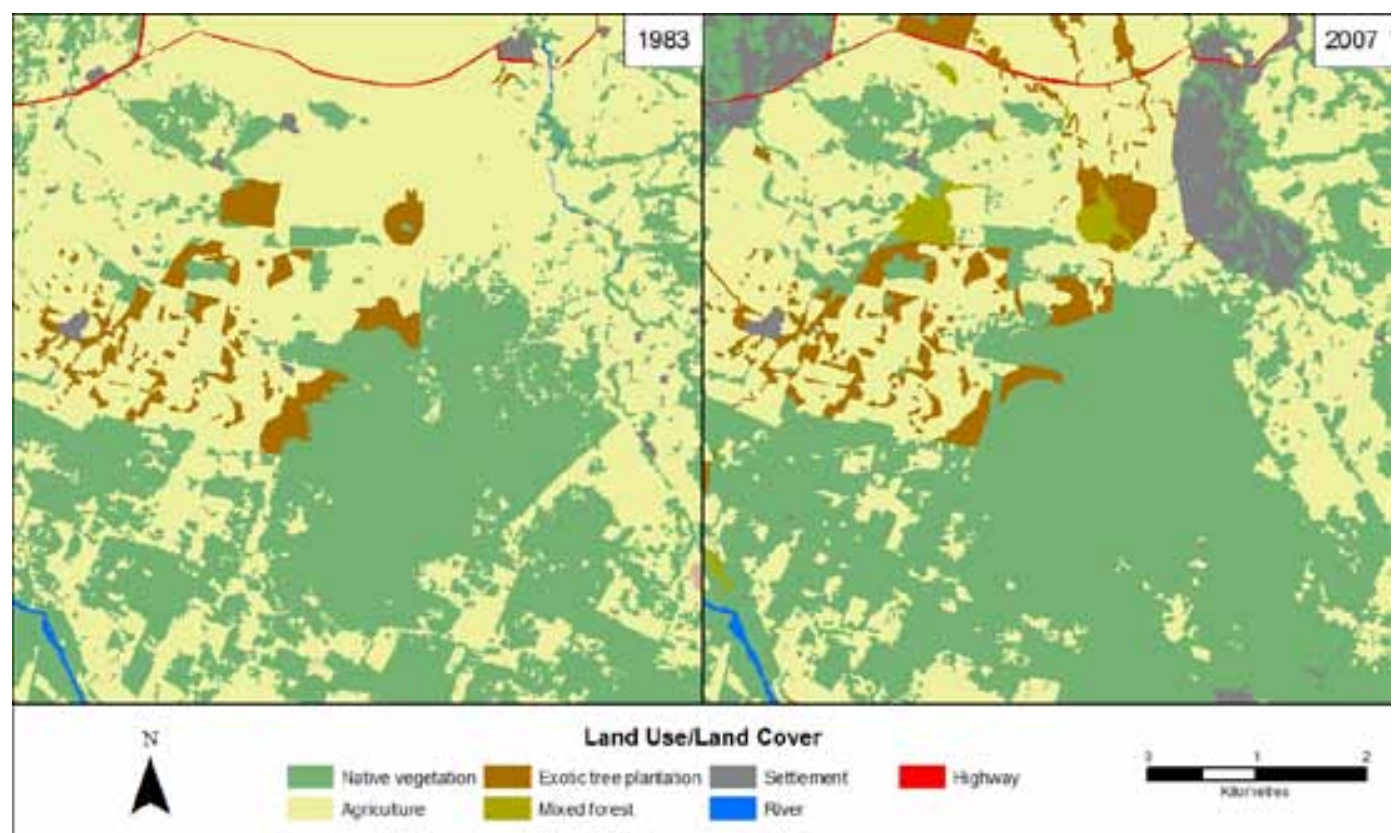

Figure 2. Land use/land cover maps in 1983 (left) and 2007 (right) of the study area, located in temperate forests of the La Araucanía Region, south-central Chile.

\section{3}

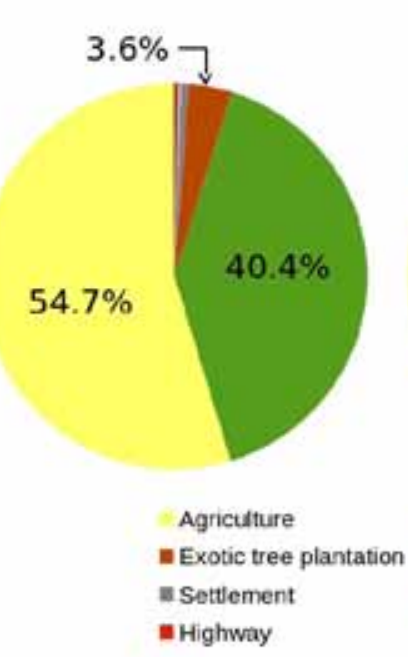

2007

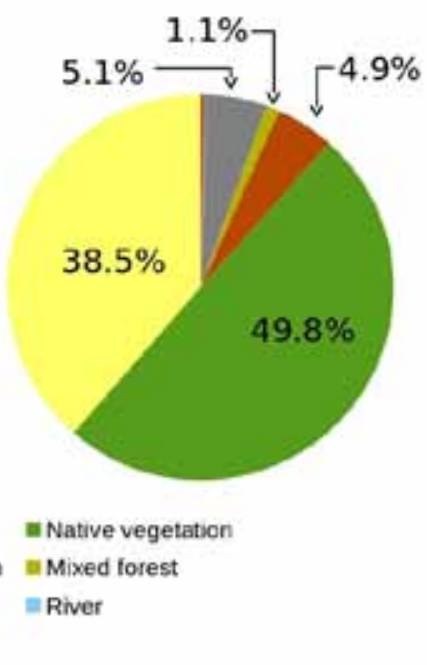

Figure 3. Landscape area distribution in 1983 (left) and 2007 (right) of the study area, located in temperate forests of the La Araucanía Region, south-central Chile. Only total landscape area percentages above $1.0 \%$ are shown. 
although to a lesser extent, to exotic tree plantation and native vegetation (19.63\% and $17.61 \%$, respectively). The settlement class switched its most frequent neighbor from agriculture to native vegetation; the adjacency percentage of settlement went from 11.56 to $75.12 \%$ for $n a$ tive vegetation and from 76.94 to $15.65 \%$ for agriculture. By 2007, 100\% of the river edges were adjacent to native vegetation, unlike in 1983 , where $31.72 \%$ of the edges were adjacent to agriculture.

\section{Native vegetation and other class metrics}

The metrics calculated for the native vegetation class, and their percentages of change for the study period are presented in Table 2. Native vegetation showed an increase in total area from $1,617.76$ to $1,992.26$ ha. The largest patch of native vegetation also increased in size, representing $23.77 \%$ of the landscape in 1983 and $38.80 \%$ in 2007.

Metrics related to fragmentation are based on the number of patches, which decreased from 401 to 220, and both the mean patch area and effective mesh size, which increased by $124.24 \%$ and $157.70 \%$, respectively, in the study period. The relatively large numbers for the patch area coefficient of variation indicate great variability in patch sizes for both years. Regarding isolation and connectivity, the mean radius of gyration increased by $26.10 \%$, the mean proximity index decreased by $39.48 \%$ and the mean Euclidean nearest neighbor distance increased by $48.55 \%$ in the study period.

The metrics for agriculture, settlement, exotic tree plantation and mixed forest are presented in Table 3. Total area, patch number and mean patch size are reported for these classes (table 3). Values for each year and percent change are presented for all classes except mixed forest because this class was only present in 2007.

\section{Discussion}

Our study shows a case of increased native vegetation cover and decreased fragmentation over a 24-year period. In those 24 years, the landscape became more heterogeneous, as indicated by the landscape-level metrics (increase in SIDI and SIEI and decrease in LPI). These results can be explained by the increase in the number of types of land use/land cover classes (mixed forest appeared in 2007) and a more uniform distribution of area between the classes. Native vegetation cover increased in area, decreased in fragmentation, and became the dominant class in the landscape. Settlements showed the highest percentage increase in terms of area and a change in its most common neighboring class, from agriculture to native vegetation. Additionally, the exotic tree plantation area increased, and a new class of landscape, mixed forest, appeared by 2007.

The change observed in native vegetation differs from the trend seen in the region overall. In the La Araucanía Region, native forest decreased by 4.1\% between 1993 and 2007 (CONAF, 2009). In general, temperate forest areas of South America have been rapidly decreasing (Lara et al., 2012). Consequently, increasing forest loss and fragmentation have been the most common trends reported for southern temperate forest landscapes (Echeverría et al., 2006; Altamirano and Lara, 2010; Carmona and Nahuelhual, 2012, Miranda et al., 2015). However, we suggest that studying local cases and the underlying contexts that may influence native vegetation recovery could potentially be informative for the sustainable management of native forest. Furthermore, as far as we know, forest recovery has generally not been reported for temperate forests of southern South America, except for Díaz et al. (2011), who reported the re-growth of native forest in abandoned farms in Chiloé Island. However, these authors focused their studies on the farm level rather than examining heterogeneous landscape dynamics. Additionally, Zamorano-Elgueta et al. 
Table 1. Adjacency matrix. The columns show the percentage of total neighboring pixels of the land use/land cover class that are adjacent to the other classes.

\begin{tabular}{|c|c|c|c|c|c|c|c|}
\hline & $\begin{array}{c}\text { Native } \\
\text { vegetation }\end{array}$ & Agriculture & $\begin{array}{l}\text { Exotic tree } \\
\text { plantation }\end{array}$ & Mixed forest & Settlement & River & Highway \\
\hline \multicolumn{8}{|l|}{1987} \\
\hline Native vegetation & - & 85.88 & 14.87 & & 11.56 & 67.89 & 9.49 \\
\hline Agriculture & 96.18 & - & 84.26 & & 76.94 & 31.72 & 84.95 \\
\hline $\begin{array}{l}\text { Exotic tree } \\
\text { plantation }\end{array}$ & 1.80 & 9.09 & - & & 4.24 & 0.00 & 0.00 \\
\hline Settlement & 0.28 & 1.71 & 0.87 & & - & 0.00 & 5.32 \\
\hline River & 1.42 & 0.59 & 0.00 & & 0.00 & - & 0.24 \\
\hline Highway & 0.32 & 2.58 & 0.00 & & 0.00 & 0.39 & - \\
\hline \multicolumn{8}{|l|}{2007} \\
\hline Native vegetation & & 75.08 & 13.65 & 17.61 & 75.12 & 100.00 & 12.56 \\
\hline Agriculture & 81.72 & - & 79.77 & 57.86 & 15.65 & 0.00 & 52.59 \\
\hline $\begin{array}{l}\text { Exotic tree } \\
\text { plantation }\end{array}$ & 3.35 & 17.97 & - & 19.63 & 2.05 & 0.00 & 11.51 \\
\hline Mixed forest & 0.65 & 1.97 & 2.97 & - & 0.90 & 0.00 & 0.67 \\
\hline Settlement & 12.64 & 2.42 & 1.41 & 4.06 & - & 0.00 & 22.67 \\
\hline River & 0.99 & 0.00 & 0.00 & 0.00 & 0.00 & - & 0.00 \\
\hline Highway & 0.59 & 2.26 & 2.19 & 0.84 & 6.29 & 0.00 & - \\
\hline
\end{tabular}

Table 2. Metrics for the native vegetation class in 1983 and 2007 and the percent change of the 24-year period in the study area, located in temperate forests of the La Araucanía Region, south-central Chile.

\begin{tabular}{lccc}
\hline Metric & 1983 & 2007 & Change (\%) \\
\hline Total area (ha) & $1,617.76$ & $1,992.26$ & 23.15 \\
Number of patches & 401 & 220 & -45.14 \\
Mean patch area (ha) & 4.03 & 9.06 & 124.47 \\
Mean radius of gyration (m) & 42.22 & 53.24 & 26.10 \\
Mean proximity index & $31,341.84$ & $18,968.97$ & -39.48 \\
Mean Euclidean nearest neighbor distance (m) & 25.63 & 38.07 & 48.55 \\
Effective mesh size (ha) & 235.63 & 607.20 & 157.70 \\
\hline
\end{tabular}

(2015) described the natural regeneration of native vegetation as a partial compensation for native forest replacement by commercial plantations, and Echeverría et al. (2012) reported marginal native vegetation regeneration associated with agricultural land abandonment. Nevertheless, these authors reported an overall decrease of native forest and an increase in the fragmentation level.

Our results showed not only an increase in native vegetation cover but also a decrease in the level of fragmentation. The $124.24 \%$ increase in the effective mesh size index supports this observation. Additionally, the reduction in the number of patches, along with the increase in mean patch size, provides further information on the local process of (de)fragmentation (Pauchard et al., 2006). These metrics suggest that many patches merged during the study period. In contrast, isolation and connectivity metrics showed that native vegetation patches were more isolated in 2007 than in 1983. This may seem to contradict the decrease in the fragmentation level. However, the proximity reduction among patches could be explained by the spatial configuration of the class. In 1983, there were many small patches close to each other, which had been produced by fragmentation processes before 1983. These 
Table 3. Metrics for the land use/land cover classes in 1983 and 2007 and the percent change in the 24-year period in the study area, located in temperate forests of the La Araucanía Region, south-central Chile.

\begin{tabular}{|c|c|c|c|}
\hline Land use/land cover classes and metrics & 1983 & 2007 & Change (\%) \\
\hline \multicolumn{4}{|l|}{ Agriculture } \\
\hline Total area (ha) & $2,189.10$ & $1,542.50$ & -29.54 \\
\hline Number of patches & 190 & 169 & -11.05 \\
\hline Mean patch area (ha) & 11.52 & 9.13 & -20.75 \\
\hline \multicolumn{4}{|l|}{ Settlement } \\
\hline Total area (ha) & 26.39 & 203.25 & 670.18 \\
\hline Number of patches & 20 & 45 & 125.00 \\
\hline Mean patch area (ha) & 1.32 & 4.52 & 242.42 \\
\hline \multicolumn{4}{|l|}{ Exotic tree plantation } \\
\hline Total area (ha) & 144.27 & 197.82 & 37.12 \\
\hline Number of patches & 70 & 116 & 65.71 \\
\hline Mean patch area (ha) & 2.06 & 1.71 & -17.25 \\
\hline \multicolumn{4}{|l|}{ Mixed forest } \\
\hline Total area (ha) & - & 44.09 & - \\
\hline Number of patches & - & 11 & - \\
\hline Mean patch area (ha) & - & 4.01 & - \\
\hline
\end{tabular}

groups of small patches reduced the mean distance among patches. When the small patches connected with larger ones, these become one large patch with fewer neighbor patches; thus, the proximity between them was reduced. Despite the higher isolation, the increase in the radius of gyration implies a better connectivity. This index measures the extent of patches in the landscape, where large or elongated patches present larger values than other shapes (McGarigal et al., 2002).

All of the rivers edges in the area were covered by native vegetation. This improves connectivity because river vegetation can be an important wildlife corridor (Hilty and Merenlender, 2004). The observed changes can be considered positive for the conservation of species that are sensitive to forest loss in the area. For example, Gálvez et al. (2013) found, in the same area, that the occupancy rates of Guiñas (Leopardus guigna) are positively associated with native vegetation cover (shrubland and forest). The occurrence probability of other species with specific habitat requirements, such as Rufous-legged Owls (Strix rufipes), are also positively correlated with forest cover (Ibarra et al., 2012). In the aforementioned studies, both top predator species were recorded outside protected areas along rivers, suggesting that these corridors are a key element in providing connectivity between higher and lower habitats in Andean forested watersheds. To understand the potential effects of increasing native vegetation cover on wildlife conservation over time, these forests need to be monitored over the long term. Additionally, the age and quality of forest stands must be considered; structurally degraded forests comprise a significant proportion of the remnant native vegetation in the temperate rainforests of Chile (Armesto et al., 2009), and these are known to be poorer habitats for wildlife than are structurally complex forest stands (Ibarra and Martin 2015). Structurally complex native forests (e.g., those with the presence of large-decaying trees, snags and a dense understory) have important habitat attributes for wildlife, but these attributes are generally lacking in secondary forests (Ibarra and Martin 2015). Thus, we suggest that standlevel forest complexity needs to be considered in 
future evaluations of forest recovery, especially as habitat for wildlife.

Exotic tree plantations also increased in the area. Unlike native vegetation recovery, the increase of exotic tree plantations is also observed at the regional level. In the La Araucanía Region, exotic tree plantations increased by $62.9 \%$ between 1993 and 2007 (CONAF, 2009). The $37.1 \%$ increase in exotic tree plantations in our study area is lower than the regional trend. However, we also observed the appearance of mixed forest (exotic with native) patches. According to Lara et al. (2012), exotic tree plantations have been the second cause of native forest replacement in the La Araucanía Region. The 1974 Law Decree 701 established economic incentives to afforestation (Niklitschek, 2007), and after the implementation of this decree, exotic species have been extensively planted for pulp and wood production in south-central Chile. In the study area, the increase in exotic tree plantation is due to the presence of new, small patches rather than the expansion of existing plantations. This suggests that exotic tree plantations may be used as a complementary economic activity rather than a main productive land use. Further studies are required to understand the role of exotic tree plantations in a multifunction landscape.

The large percent increase in residential area (670.26\%) is not surprising because the county showed the highest population growth rate in the Region between 1982 and 2002 (INE, 2008). The increasing residential use of the landscape is likely associated with tourist activity in the area because some residential patches correspond to secondary residences. The natural appeal of the area has generated the development of the tourism industry, thereby increasing the number of vacation houses and private protected areas. Further, Hidalgo and Zunino (2011) reported that over the last 10 years, new residents have arrived in Pucón searching for spiritually oriented and natural livelihoods. The increase in population and settlements implies a growing human presence in the area but also suggests a greater concern for nature conservation, considering the interests of both the tourists and new residents (Hidalgo and Zunino, 2011). Pucón County is an important tourist destination due to its natural attractions, such as mountains, forests, volcanoes, rivers, and lakes (Municipalidad de Pucón, 2007).

In 1983, residential areas were mainly adjacent to agricultural lands, but 24 years later, $75.12 \%$ of the class edges were adjacent to native vegetation. This suggests that residents may prefer forested areas to other land covers. Native vegetation and other natural features not only attract tourists but also new permanent and seasonal residents who have arrived in the county looking for a pleasant environment (Hidalgo and Zunino, 2011). The native vegetation patterns observed by 2007 could be related to changes in main economic activities, such as the increase of nature-based activities (e.g., tourism and residential projects), along with a considerable decrease in agriculture (Aide and Grau, 2004).

The relations discussed above and other drivers of landscape change need further research, such as in market incentives for agriculture and forestry, public policies regarding land use and the abandonment of agricultural livelihood. Improving the current knowledge on the forces underlying such landscape changes will be necessary to anticipate future changes and improve landscape management. Furthermore, understanding the drivers of change will allow some hypotheses of forest recovery to be tested, such as forest transition. This hypothesis suggests that forest recovery is related to agricultural abandonment, where local agriculture cannot compete with industrial farming elsewhere (Aide and Grau, 2004). In recent decades, forest regeneration in Europe has been associated with population decreases and agriculture abandonment (e.g., Falcucci et al., (2007) in Italy and Sivrikaya et al. (2007) in Turkey). In Europe, however, forest recovery has been mostly driven by deliberate exotic tree plantation rather than natural regeneration (Mather, 2008), unlike what we observed in this study. In contrast, in 
Norway, forest recovery has been related to tourism development in former agricultural lands (Olsson et al., 2000). Furthermore, urbanization processes and changes in attitude towards forest conservation may also have a role in forest recovery (Klooster, 2003).

This study is a first approach to understanding a local case of native vegetation recovery in the temperate forest of southern South America. In this research, we provide evidence that a process of forest transition is taking place in Pucón County. Nevertheless, the recovery of native forest is the main trend in neither the country nor the La Araucanía Region. The observed recovery of native vegetation could be considered in a context of a deforested frontier that is moving slightly back. Further investigation is required to explore whether native forest is increasing in other areas of Chile and in which geographical and socioeconomic contexts. This research may be used to help identify the socio-economic activities that are shaping the landscape and which of these are compatible with the recovery of native forests.

\section{Acknowledgements}

The authors thank the support and valuable comments from Nicolás Gálvez, Jerry Laker, Piergiorgio DiGiminiani and Daniela Bonacic, along with the helpful suggestions of two anonymous reviewers. We also thank the in the field assistance of Pamela Torres, Antonia Barreau and Tucker Murphy. The Campus Villarrica of Pontificia Universidad Católica de Chile provided the aerial photographs for this study. We also thank the support of Vicerrectoría de Investigación from the Pontificia Universidad Católica de Chile (Internationalization Grant Agreement PUC1566-MINEDUC), Rufford Small Grants for Nature Conservation (14397-2), the Center for Intercultural and Indigenous Research - CIIR (CONICYT/FONDAP/15110006) and CONICYT/ FONDECYT/11160932.

\title{
Resumen
}

\begin{abstract}
R. Petitpas, J.T. Ibarra, M. Miranda y C. Bonacic. 2016. Patrones espaciales en un período de 24 años muestran un caso de aumento de la vegetación nativa y disminución de la fragmentación en los paisajes templados andinos, Chile. Cien. Inv. Agr. 43(3):384-395. Los cambios en los patrones espaciales fueron estudiados en un paisaje templado de la región de La Araucanía, Chile. Se hicieron mapas de cobertura y uso del suelo a partir de fotografías aéreas de los años 1983 y 2007. Los cambios en composición y configuración del paisaje se obtuvieron a partir de métricas y una matriz de adyacencia. Para el año 2007, la cobertura dominante cambió desde agricultura a vegetación nativa. Las áreas residenciales presentaron el mayor aumento porcentual (670\%) y una importante relación de adyacencia con la vegetación nativa. La vegetación nativa aumentó en 375 ha, pero el número de parches de esta disminuyó en un $45 \%$ y el área media de los parches aumentó un $124 \%$, lo que indica una disminución en la fragmentación. El incremento del turismo y la preferencia de espacios naturales entre los nuevos residentes del área sería la principal fuerza de cambio detrás de la recuperación de la vegetación nativa. Considerando la pérdida actual de la vegetación nativa en el área, se hace importante que futuros estudios consideren casos específicos de recuperación de esta, para así entender los factores asociados a este proceso. Esta investigación es una primera aproximación para entender la recuperación y disminución de la fragmentación de la vegetación nativa de los ecosistemas templados de América del Sur.
\end{abstract}

Palabras clave: Bosque templado, cambios en el paisaje, fragmentación, recuperación de vegetación nativa. 


\section{References}

Altamirano, A., and A. Lara. 2010. Deforestación en ecosistemas templados de la precordillera andina del centro-sur de Chile. Bosque 31: 53-64.

Aide, M., and M. Grau. 2004. Globalization, migration, and Latin American ecosystems, Science 305: 1915-1916.

Armesto, J., C. Smith-Ramírez, M. Carmona, J. Celis-Diez, I. Díaz, A. Gaxiola, A. Gutiérrez, M. Núñez-Avila, C. Pérez, and R. Rozzi. 2009. Old-growth temperate rainforests of South America: conservation, plant-animal interactions, and baseline biogeochemical processes. In: C. Wirth, G. Gleixner and M. Heimann (eds.). Old-growth forests: function, fate and value. Springer, Berlin.

Carmona, A., and L. Nahuelhual. 2012. Combining land transitions and trajectories in assessing forest cover change. Applied Geography 32: 904915.

CONAF. 2009. Catastro de uso del suelo y vegetación, período 1993-2007: monitoreo y actualización, región de La Araucanía. Corporación Nacional Forestal de Chile. Available online at: http://www.conaf.cl/RecursosForestales/ BosqueNativo/Catastro (Website accessed: January, 2012).

Díaz, G., L. Nahuelhual, C. Echeverría, and S. Marín. 2011. Drivers of land abandonment in Southern Chile and implications for landscape planning. Landscape and Urban Planning 99: 207-217.

Echeverría, C., D. Coomes, J. Salas, J.M. Rey Benayas, A. Lara, and A. Newton. 2006. Rapid deforestation and fragmentation of Chilean temperate forests. Biological Conservation 130: 481-494.

Echeverría, C., A. Newton, L. Nahuelhual, D. Coomes, and J.M. Rey-Benayas. 2012. How landscapes change: integration of spatial patterns and human processes in temperate 60 landscapes of southern Chile. Journal of Applied Geography 32: 822-831.

Falcucci, A., L. Maiorano, and L. Boitani. 2007. Changes in land-use/land-cover patterns in Italy and their implications for biodiversity conservation. Landscape Ecology 22: 617- 631.
Gálvez, N., F. Hernández, J. Laker, H. Gilabert, R. Petitpas, C. Bonacic, A. Gimona, A. Hester, and D. Macdonald. 2013. Forest cover outside protected areas plays an important role in the conservation of the Vulnerable guiña Leopardus guigna. Oryx 47: 251-258.

Hernández, A., M. Miranda, E.C. Arellano, S. Saura, and C. Ovalle. 2015. Landscape dynamics and their effect on the functional connectivity of a Mediterranean landscape in Chile. Ecological Indicators 48: 198-206.

Hernández, A., M. Miranda, E.C. Arellano, and C. Dobbs. 2016. Landscape trajectories and their effect on fragmentation for a Mediterranean semiarid ecosystem in Central Chile. Journal of Arid Environments 127: 74-81.

Hidalgo, R. and H.M. Zunino. 2011. Negocios inmobiliarios en centros turísticos de montaña y nuevos modos de vida: el papel de los migrantes de amenidad existenciales en la Comuna de Pucón - Chile. Estudios y Perspectivas en Turismo 20: 307-326.

Hilty, J., and A. Merenlender. 2004. Use of riparian corridors and vineyards by mammalian predators in Northern California. Conservation Biology 18: $126-135$.

Hunsaker, C., and R. Hughes. 2002. Effects of landscape change on the physical and chemical components of aquatic ecosystems. In: K, Gutzwiller (ed.). Applying landscape ecology in biological conservation. Springer-Verlag, New York. 22 pp.

Ibarra, J.T., N. Gálvez, A. Gimona, T. Altamirano, I. Rojas, A. Hester, J. Laker and C. Bonacic. 2012. Rufous-legged Owl (Strix rufipes) and Austral Pygmy Owl (Glaucidium nanum) stand use in a gradient of disrupted and old growth Andean temperate forests, Chile. Studies on Neotropical Fauna and Environment 47: 33-40.

Ibarra, J.T., and K. Martin. 2015. Biotic homogenization: loss of avian functional richness and habitat specialists in disturbed Andean temperate forests. Biological Conservation 192: 418-427.

INE. 2008. Población censos 1960, 1970, 1982, 1992 y 2002, según país, Región De La Araucanía, provincias y comunas. Instituto Nacional de Estadísticas de Chile. Available online at: http:// 
www.inearaucania.cl/contenido.aspx?id_contenido=13 (Website accessed April 2012).

Klooster, D. 2003. Forest transitions in Mexico: Institutions and forests in a globalized countryside. The Professional Geographer 55: 227-237.

Lara, A., M. Solari, M. Prieto and M. Peña. 2012. Reconstrucción de la cobertura de la vegetación y uso del suelo hacia 1550 y sus cambios a 2007 en la ecorregión de los bosques valdivianos lluviosos de Chile $\left(35^{\circ}-43^{\circ} 30^{\prime} \mathrm{S}\right)$. Bosque 33: 13-23.

Li, X., H. He, R. Bu, Q. Wen, Y. Chang, Y. Hu and Y. Li. 2005. The adequacy of different landscape metrics for various landscape patterns. Pattern Recognition 28: 2626-2638.

Mather, A.S. 2008. Forest transition theory and the reforesting of Scotland. Scottish Geographical Journal 120: 83-98.

McGarigal, K., S. A. Cushman, M. C. Neel and E. Ene. 2002. FRAGSTATS: Spatial Pattern Analysis Program for Categorical Maps. Computer software program produced by the authors at the University of Massachusetts, Amherst.

Miranda, A., A. Altamirano, L. Cayuela, F. Pincheira, and A. Lara. 2015. Different times, same story: Native forest loss and landscape homogenization in three physiographical areas of south-central of Chile. Applied Geography 60: 20-28.

Moore-Colyer, R., and A. Scott. 2005. What kind of landscape do we want? Past, present and future perspectives. Landscape Research 30: 501-523.

Municipalidad de Pucón. 2007. Actualización plan regulador comunal de Pucón. Etapa II: diagnostico. Available online at: http://www.municipalidadpucon.cl (Website accessed January 2012).
Newton, A., L. Cayuela, C. Echeverría, J. Armesto, R. Del Castillo, D. Golicher, D. Geneletti, M. Gonzales-Espinosa, A. Huth, F. López-Barrera, L. Malizia, A. Premoli, N. Ramírez-Marcial, J.M. Rey Benayas, N. Rüger, C. Smith-Ramírez, and G. Williams-Linera. 2009. Toward integrated analysis of human impacts on forest biodiversity: lessons from Latin America. Ecology and Society 14: 2.

Olsson, E.G., A. Gunnar, and S. Grenne. 2000. Landscape change patterns in mountains, land use and environmental diversity, Mid-Norway 19601993. Landscape Ecology 15: 155-170.

Parody, J., F. Cuthbert, and E. Decker. 2001. The effect of 50 years of landscape change on species richness and community composition. Global Ecology and Biogeography 10: 305-313.

Pauchard, A., M. Aguayo, and P. Alaback. 2006. Cuantificando la fragmentación del paisaje: las métricas y sus significados ecológicos. In: A. Grez, J. Simonetti and R. Bustamante (eds.). Biodiversidad en ambientes fragmentados de Chile: patrones y procesos a diferentes escalas. Editorial Universitaria. Santiago, Chile. 26 pp.

Sivrikaya, F., G. Çakir, A.İ. Kadioğullari, S. Keleş, E.Z. Başkent, and S. Terzioğlu. 2007. Evaluating land use/land cover changes and fragmentation in the Camili forest planning unit of Northeastern Turkey from 1972 to 2005. Land Degradation \& Development 18: 383-396.

Zamorano-Elgueta, C., J.M. Benayas, L. Cayuelas, S. Hantson, and D. Armentaras. 2015. Native forest replacement by exotic plantations in southern Chile (1985-2011) and partial compensation by natural regeneration. Forest Ecology and Management 345: 10-20. 